\title{
Postcolonial Resistance of Western Imperialist Ideology: Constructing Identities of Others as Violent Savages
}

\author{
Menia Mohammad Almenia \\ Department of English Language and Translation \\ College of Arabic Language and Social Sciences \\ Qassim University \\ Buraidah, Saudi Arabia
}

\begin{abstract}
This paper examines how hegemonic discourse, or the ideology of a dominant society has essentialized, fixed, and divided identities through the construction of binary division of Western's ideology as civilized and Others as savages. The development of postcolonial theory will be introduced with special consideration to Said's (1995) theory of Orientalism and Spivak's (1988) concept of "silencing the Others." Sample Western literary texts will show a concerted expression of colonial ideology supporting the concept of binary divisions. These will include The Tempest by William Shakespeare (1990), Robinson Crouse by Daniel Defoe (1899), Jane Eyre by Charlotte Bronte (2001), and Passage to India by E. M. Foster (1985). In contrast, literary works by minority authors, mainly postcolonialists, will be examined and considered according to how effectively they resist Western imperialist ideology.
\end{abstract}

Keywords: constructing, identities, ideology, others, postcolonial

Cites as: Almenia, M. M. (2018). Postcolonial Resistance of Western Imperialist Ideology:

Constructing Identities of Others as Violent Savages. Arab World English Journal for

Translation \& Literary Studies, 2 (4). $130-143$.

DOI: http://dx.doi.org/10.24093/awejtls/vol2no4.9 